\title{
Transaminase activity in the rumen liquor of sheep
}

\author{
By ABDUR REKIB* AND D. P. SADHU† \\ Indian Veterinary Research Institute, Izatnagar, UP, India
}

(Received 24 April 1967-Accepted 29 fanuary 1968)

\begin{abstract}
I. The presence of transaminase activity in rumen contents has been demonstrated. The level of activity varied with time after feeding and was infuenced by the nature of the diet.

2. Rumen contents from a sheep given a diet containing casein showed greater transaminase activity at $2 \mathrm{~h}$ than at $6 \mathrm{~h}$ after feeding. Conversely, with a diet containing urea and maize, the activity was higher at $6 \mathrm{~h}$ than at $2 \mathrm{~h}$ after feeding.

3. The greater part of the transaminase activity of rumen liquor was associated with the fraction containing protozoa and food residues while the cell-free fraction contained no transaminase activity under the experimental conditions.
\end{abstract}

Enzymic transamination first reported by Braunstein \& Kritzmann (1937-8) threw new light on amino acid metabolism. The scope of the transamination reaction is broad and virtually all the amino acids participate in enzymic transamination and in protein synthesis (Cammarata \& Cohen, 1950; Feldman \& Gunsalus, 1950; Meister $\&$ Tice, I950). The finding that micro-organisms synthesize amino acids from the corresponding $\alpha$-keto acids by means of transamination lends strong support to the key role of transamination in amino acid metabolism and protein synthesis in the rumen. Evidence that transaminase activity exists in rumen fluid has already been presented (Otagaki, Black, Goss \& Kleiber, 1955).

In the present experiment an attempt was made to study the transaminase activity of the rumen fluid under different feeding regimes. The effect of differential centrifugation on the transaminase activity was also noted.

\section{EXPERIMENTAL}

Animals and rations. Four sheep, 2-3 years of age, with rumen fistulas were given the following rations:

$\begin{array}{ll}\text { Ration } F_{1} & \text { Nandi cattle feed } 300 \mathrm{~g} \\ \text { Ration } F_{2} & \text { Nandi cattle feed } 300 \mathrm{~g} \text {, urea } 5 \mathrm{~g} \\ \text { Ration } F_{3} & \text { Nandi cattle feed } 300 \mathrm{~g} \text {, casein } 30 \mathrm{~g} \\ \text { Ration } \mathrm{F}_{4} & \text { Maize meal } 300 \mathrm{~g} \\ \text { Ration } \mathrm{F}_{5} & \text { Maize meal } 300 \mathrm{~g} \text {, urea } 5 \mathrm{~g}\end{array}$

The percentage composition of the Nandi cattle feed used was: dry matter $90.8 \mathrm{I}$, crude protein 23.01 , crude fat 6.12 , crude fibre 12.54 , nitrogen-free extract $55^{\circ} 93$, total ash $2 \cdot 4$.

The rations were given in two equal parts, one half in the morning at about $08.00 \mathrm{~h}$

* Present address: Department of Chemistry and Biochemistry, Punjab Agricultural University Ludhiana (Pb.) India.

$\uparrow$ Present address: Bengal Veterinary College, Calcutta 37, India. 
and the second half at $15.00 \mathrm{~h}$. Samples of rumen liquor were taken 2 and $6 \mathrm{~h}$ after the morning feed. The animals were allowed to graze for $\mathrm{t} h$ at $\mathrm{i} 6.00 \mathrm{~h}$ and extra green food was provided after grazing. At each sampling time about $250 \mathrm{ml}$ of the rumen liquor were drawn from different parts of the rumen. Samples were strained through a double layer of fine muslin cloth and immediately stored in a refrigerator for analysis. Sheep were allowed ro days to adapt to each ration before samples of rumen liquor were taken for analysis. The animals were given each diet in rotation and at least five collections were taken randomly from each sheep on a particular ration.

Reagents and analytical techniques. Sodium phosphate buffer $(\mathrm{O} \cdot \mathrm{I} \mathrm{M}) \mathrm{pH} 7 \cdot 4$; sodium aspartate $(0.2 \mathrm{M})$; sodium a-oxoglutarate $(0 . \mathrm{I} \mathrm{M})$; metaphosphoric acid $(10 \%, \mathrm{w} / \mathrm{v})$; aniline-citrate $(100 \%, \mathrm{w} / \mathrm{v}) ; 2,4$-dinitrophenyl hydrazine $(0.1 \%, \mathrm{w} / \mathrm{v})$; alcoholic potassium hydroxide $(2 \cdot 5 \%, \mathrm{w} / \mathrm{v})$, water-saturated toluene and standard pyruvic acid solution $(800 \mu \mathrm{g} / \mathrm{ml})$ were prepared. The general procedure for the determination of transaminase activity was similar to the colorimetric procedure for the estimation of glutamic oxalo-acetic transaminase of the blood (Sall, Richards, Harrison \& Myerson, I957). The strained rumen liquor was taken in portions of $0.5 \mathrm{ml}$ instead of $0.2 \mathrm{ml}$ as used by Sall et al. (1957) for blood serum. The amount of pyruvic acid formed during a $10 \mathrm{~min}$ incubation period was calculated by subtracting the preformed pyruvic acid of the rumen liquor from the total quantity present after incubation with substrate. The enzyme activity was expressed as the amount $(\mu \mathrm{g})$ of pyruvic acid produced per $\mathrm{ml}$ strained rumen liquor during to min incubation at $39^{\circ}$ (Blincoe \& Dye, I958).

Differential centrifugation of strained rumen liquor. Two sheep were maintained on the basal ration $\left(\mathrm{F}_{1}\right)$ and samples of rumen liquor were collected $2 \mathrm{~h}$ after feeding. Portions ( $5 \mathrm{ml}$ ) were strained, diluted to Io $\mathrm{ml}$ with $0.02 \mathrm{M}$-phosphate buffer ( $\mathrm{pH}_{7} \cdot 4$ ) and centrifuged for $5 \mathrm{~min}$ at $325-500 \mathrm{~g}$ at a temperature of $5^{\circ}$. The supernatant fluid was separated with a Pasteur pipette. Particles of food and protozoa sedimented by this procedure were resuspended in $\mathrm{I} \mathrm{ml}$ of $0.05 \mathrm{M}$-phosphate buffer (Fraction $\mathrm{A}$ ). The supernatant fraction $(5 \mathrm{ml})$ was diluted to $10 \mathrm{ml}$ with $0.02 \mathrm{ml}$ phosphate buffer and centrifuged for $45 \mathrm{~min}$ at $3000 \mathrm{~g}$ at $5^{\circ}$. The supernatant fluid was carefully separated from the bacterial sediment with a Pasteur pipette. Bacteria were washed again with Io $\mathrm{ml}$ of $0.02 \mathrm{M}$-phosphate buffer centrifuged at $3000 \mathrm{~g}$ for $45 \mathrm{~min}$. The brownish sediment was separated from the supernatant fluid. The washed bacterial pellet was resuspended in $\mathrm{I} \mathrm{ml}$ of $0.05 \mathrm{M}$-phosphate buffer $\mathrm{pH} 7.4$ (Fraction $\mathrm{B}$ ). The fractions thus prepared were: $A$, food particles and protozoa; $\mathrm{B}$, washed bacterial suspension; $\mathrm{C}$, cell-free soluble fraction of the rumen liquor; $\mathrm{D}$, strained rumen liquor.

Transaminase activity was determined as stated above.

\section{RESUI.TS}

The enzyme activity was found to vary greatly $\left(133^{\cdot} 9^{-}-371 \cdot 4\right.$ units $/ \mathrm{ml}$ ) from feed to feed. The mean transminase activity (200 observations) was 219.6 (ignoring differences attributable to rations or time of sampling). The mean transaminase activity was greater at $2 \mathrm{~h}(242.9 \mathrm{units} / \mathrm{ml})$ than $6 \mathrm{~h}$ (196.3 units $/ \mathrm{ml})$ after feeding. The results pre- 
sented in Table 1 show the mean transaminase activity of the rumen liquor at $2 \mathrm{~h}$ and at $6 \mathrm{~h}$ after ingestion of the different feeds. The value at $6 \mathrm{~h}$ was less than that at $2 \mathrm{~h}$, except with the urea-supplemented high-nitrogen feed $\left(\mathrm{F}_{2}\right)$ when the transaminase activity was more at $6 \mathrm{~h}$ than at $2 \mathrm{~h}$.

The results presented in Table 2 show that the concentrations of transaminase in the rumen liquor were very variable from animal to animal and even on different occasions in the same animal. However, it is clear that transaminase activity was greater in Fraction A, i.e. food particles and protozoa, and very low in the bacterial suspension; the strained rumen liquor gave an intermediate result. There was no transaminase activity in the cell-free soluble fraction of the rumen contents.

Table 1. Transaminase activity in the rumen of sheep given rations $F_{1}-F_{5}$

(Mean values with their standard errors for four sheep)

\begin{tabular}{|c|c|c|c|c|c|c|}
\hline $\begin{array}{l}\text { Time after } \\
\text { feeding } \\
\text { (h) }\end{array}$ & $\begin{array}{c}F_{2} \\
\text { (Nandi } \\
\text { cattle } \\
\text { feed) }\end{array}$ & $\begin{array}{c}F_{2} \\
\text { (Nandi } \\
\text { cattle } \\
\text { feed }+ \\
\text { urea) }\end{array}$ & $\begin{array}{c}F_{3} \\
\text { (Nandi } \\
\text { cattle } \\
\text { feed + } \\
\text { casein) }\end{array}$ & $\begin{array}{c}\mathrm{F}_{4} \\
\text { (maize } \\
\text { meal) }\end{array}$ & $\begin{array}{c}F_{5} \\
\text { (maize } \\
\text { mealt } \\
\text { urea) }\end{array}$ & $\begin{array}{c}\text { Approximate } \\
\text { SE of } \\
\text { differences } \\
\text { between } \\
\text { dietary means }\end{array}$ \\
\hline 2 & $\begin{array}{r}23 r \cdot 6 \\
\pm 17 \cdot 2\end{array}$ & $\begin{array}{r}180 \cdot 7 \\
\pm 20.9\end{array}$ & $\begin{array}{r}371.4 \\
\pm 18.7\end{array}$ & $\begin{array}{r}162 \cdot 7 \\
\pm 27.5\end{array}$ & $\begin{array}{r}268.3 \\
\pm 29.2\end{array}$ & $\pm 32 \cdot 3$ \\
\hline 6 & $\begin{array}{r}188.2 \\
\pm 134\end{array}$ & $\begin{array}{r}240.2 \\
\pm 26.7\end{array}$ & $\begin{array}{r}209 \cdot 8 \\
\pm 18 \cdot 0\end{array}$ & $\begin{array}{r}133.9 \\
\pm 18.8\end{array}$ & $\begin{array}{r}209^{\circ} 6 \\
\pm 30.4\end{array}$ & $\pm 30 \cdot 5$ \\
\hline $\begin{array}{l}\text { Paired test } \\
t \text { value }\end{array}$ & $\begin{array}{l}\text { NS } \\
I \cdot 709\end{array}$ & $\begin{array}{l}\text { NS } \\
\mathbf{I} \cdot 770\end{array}$ & $\stackrel{*}{*} \cdot 361$ & $\begin{array}{l}\text { NS } \\
0.939\end{array}$ & $\begin{array}{l}\text { NS } \\
\text { I-540 }\end{array}$ & 二 \\
\hline
\end{tabular}

Table 2. Transaminase activity of different fractions of the rumen fuid of two sheep on 3 different days

\begin{tabular}{|c|c|c|c|c|}
\hline \multirow[b]{2}{*}{ Fraction } & \multicolumn{3}{|c|}{ Pyruvic acid liberated $(\mu \mathrm{g} / \mathrm{ml})$} & \multirow[b]{2}{*}{ Mean } \\
\hline & Day $\mathbf{x}$ & Day 2 & Day 3 & \\
\hline \multicolumn{5}{|c|}{ Sheep no. 10} \\
\hline Food particles and protozoa & 396 & 408 & 196 & 333 \\
\hline Washed bacterial suspension & 76 & 44 & 64 & 61 \\
\hline Cell-free supernatant fraction & 0 & 0 & $\circ$ & o \\
\hline Strained rumen liquor & 268 & 96 & 76 & 147 \\
\hline \multicolumn{5}{|c|}{ Sheep no. 52} \\
\hline Food particles and protozoa & 172 & 60 & 140 & 124 \\
\hline Washed bacterial suspension & 36 & 28 & 50 & 38 \\
\hline Cell-free supernatant fraction & 0 & $\circ$ & $\circ$ & $\circ$ \\
\hline Strained rumen liquor & 60 & 60 & 80 & 67 \\
\hline
\end{tabular}

\section{Discussion}

The results were statistically analysed to examine the effect of food on the rate of transamination (Table 1 ). Highly significant differences $(P<0.001)$ in transaminase activity were noted from feed to feed at $2 \mathrm{~h}$ after feeding. Rations containing casein induced a transaminase activity that was significantly greater than that in sheep given other rations. The transaminase activity at $6 \mathrm{~h}$ after feeding showed a significant 
difference $(P<0.05)$ from feed to feed, and a critical difference test indicated that when the ration included maize $\left(F_{4}\right)$ the transaminase activity was significantly lower than on rations $F_{2}$ and $F_{3}$.

The high transaminase activity induced by Nandi cattle feed plus casein $\left(\mathrm{F}_{3}\right)$ at $2 \mathrm{~h}$ after feeding may have been due to the fact that casein was rapidly attacked by rumen micro-organisms (McDonald, I954) to form suitable substrates for the enzyme (Annison, 1956) and it is reasonable to suppose that transamination is an active and

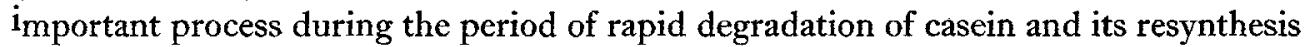
into microbial protein. A paired $t$ test showed that there was a highly significant fall in transaminase activity at $6 \mathrm{~h}$ after feeding, and it is probable that the metabolism of casein in the rumen had been completed by this time. When maize meal was used as the basal ration $\left(\mathrm{F}_{4}\right)$ a significant depression in transaminase activity was noted at both $2 \mathrm{~h}$ and $6 \mathrm{~h}$ after feeding compared with that found with rations $F_{2}$ and $F_{3}$. Maize contains a protein, zein, which is very slowly attacked by rumen micro-organisms (Annison \& Lewis, 1959) and though maize starch is rapidly fermented in the rumen, the low rate of substrate release from zein may perhaps be associated with the low levels of transaminase activity found with this ration. This suggestion is supported by the effects of adding urea to maize meal (ration $\mathrm{F}_{5}$ ) when a significantly higher transaminase activity was obtained and no significant difference in enzyme activity was noted between 2 and $6 \mathrm{~h}$ after feeding. This indicates that addition of urea to maize meal caused an increase in transaminase activity and probably resulted in an increased protein synthesis. There was no significant difference at 2 and $6 \mathrm{~h}$ after feeding in the enzyme activity of strained rumen liquor of sheep given rations $F_{1}$ and $F_{2}$. When Nandi cattle feed was used as the basal ration instead of maize there was no significant change in transaminase activity following the addition of urea to the ration. This suggests that there was a poor utilization of urea nitrogen by the micro-organisms when urea was added to a basal ration containing a high percentage of crude protein.

In the present investigations, the substrate was incubated aerobically and therefore the transaminase activity due to extracellular free enzymes, intracellular enzymes of facultative aerobic and semi-aerobic bacteria, protozoa and the phyto-enzymes could be measured. Hence, the transaminase activity measured in this study was only a part of the total transaminase activity present in the rumen, because the work of the vast majority of the anaerobic bacteria could not be detected by this method unless intracellular transaminase is liberated during autolysis of dead or dying anaerobes, as it may well be. However, it has already been shown that protozoa (Akkada \& Howard, 1962) and facultative anaerobic bacteria (Appleby, I955; Hunt \& Moore, 1958; Blackburn \& Hobson, I960) degraded casein to peptides and amino acids. Results given in Table 2 suggest that protozoa and phyto-enzymes may play an important part in protein metabolism in the rumen since a high proportion of the total transaminase activity of strained rumen liquor was present in the fraction containing protozoa and food residues.

The authors are grateful to the Indian Council of Agricultural Research, New Delhi, for awarding a senior research fellowship to one of us (A. R.). 


\section{REFERENCES}

Akkada, A. R. A. \& Howard, B. H. (I962). Biochem. F. 82, 3 I3.

Annison, E. F. (1956). Biochem. F. 64, 705.

Annison E. F. \& Lewis, D. (1959). Metabolism in the Rumen, rst ed. London: Methuen.

Appleby, J. C. (1955). F. gen. Microbiol. 12, 526.

Blackburn, T. H. \& Hobson, P. N. (1960), F. gen. Microbiol. 22, 282.

Blincoe, C. \& Dye, W. B. (1958). F. Anim. Sci. 17, 224.

Braunstein, A. E. \& Kritzmann, M. G. (1937-8). Enzymologia 2, 129.

Cammarata, P. S. \& Cohen, P. P. (1950). F. biol. Chem. 187, 439.

Feldman, L. I. \& Gunsalus, I. C. (1950). F. biol. Chem. 187, 82 1.

Hunt, W. G. \& Moore, R. O. (1958). Appl. Microbiol. 6, 36.

McDonald, I. W. (1954). Biochem. F. 56, I 20.

Meister, A. \& Tice, S. V. (r950). F. biol. Chem. 187, I73.

Otagaki, K. K., Black, A. L., Goss, H. \& Kleiber, M. (1955). F. agric. Fd Chem. 3, 948.

Sall, T., Richards, H. K., Harrison, E. \& Myerson, R. M. (1957). F. Lab. clin. Med. 50, 297. 